\title{
SURFACE ROUGHNESS OF HEAT TREATED Eucalyptus grandis WOOD
}

\author{
Gilmara Pires de Moura Palermo ${ }^{1, \star}$, João Vicente de Figueiredo Latorraca ${ }^{1}$, \\ Luiz Fernando de Moura ${ }^{2}$, Adriana Maria Nolasco ${ }^{2}$, Alexandre Monteiro de Carvalho ${ }^{1}$, \\ Rosilei Aparecida Garcia ${ }^{1}$
}

\begin{abstract}
This study aimed to evaluate surface roughness of heat treated Eucalyptus grandis wood after peripheral planning and sanding performed in directions to the grain and against the grain. For machining tests, workpieces were collected from two different regions in the radial direction, as follows: internal, nearby the pit; external, nearby the bark. Heat treatment was carried out by heating samples at a maximum temperature of $190^{\circ} \mathrm{C}$, with total treatment duration of 390 minutes. Heat treated and control samples underwent peripheral planning and sanding tests. The quality of machined surfaces was assessed by means of roughness average $(\mathrm{Ra})$ measurements across and along the grain orientation. Results indicated significant differences in surface roughness as a function of machining feed direction, sandpaper grit size, and heat treatment. Surface roughness has not shown any difference in the radial direction.
\end{abstract}

Keywords: Heat treatment, wood machining, surface quality.

\section{INTRODUCTION}

The surface quality is a very important aspect to be studied in solid wood products, as it directly affects coating and gluing processes (Kilic et al. 2006). Therefore, the quality of planed and sanded surfaces has always been one of the greatest concerns in wood industries. An important question is "what is a good quality surface?". The answer to this question strongly depends on the specific requirements related to the final use of a product. In the case of wood, surface quality is often related to esthetics rather than functional aspects. Nevertheless, surface properties and dimensional precision of wood products should meet industrial standards and quality criteria usually required by the market. Low surface roughness is not always an indispensable requirement for a wood product. For instance, a series of innovative technologies have been developed to intentionally provide rougher surfaces, as in flooring, sidings, finger joints, artificially aged furniture, and others, to confer a vintage look to wood products (Sandak and Negri 2005).

It is known that surface properties and characteristics are a result of raw material, tools, and processes adopted during machining. Therefore, it is extremely important to know how these aspects can affect surface wood quality during machining. Heat treatments have been applied to wood to improve dimensional stability and decay resistance. Several authors evaluated the mechanical and physical performance of heat-treated woods (Borrega and Kärenlampi 2008, Esteves et al. 2007, Garcia et al. 2010); however, little information is available on the effect of heat treatments on the surface roughness and machining properties of wood.

\footnotetext{
${ }^{1}$ Department of Forest Products, Rural Federal University of Rio of Janeiro (UFRRJ), Seropédica, Rio of Janeiro, Brasil.

${ }^{2}$ Department of Forest Sciences, University of São Paulo (ESALQ/USP), Piracicaba, São Paulo, Brasil.

Received: 12.04. 2012. Accepted: 18.04. 2013.

-Corresponding author: gilpalermo@hotmail.com
} 
Olek and Bonarski (2008) have studied the effect of heating on surface roughness. The authors report that the rearrangement of the crystalline portion of wood celluloses, induced by heating, resulted in a decrease in surface roughness. These differences in surface roughness might be associated with the reduction in wood equilibrium moisture content (EMC) after heat treatment, which considerably change the wood machining properties. The change in wood hygroscopicity has been attributed to chemical changes in wood components or physical changes in relative crystallinity at the surface (Bourgois and Guyonnet 1988, Obataya et al. 2000). According to Poncsak et al. (2005), when heat is applied to wood, the hemicelluloses, wood polymer relatively easy to hydrolyze, starts to be degraded and its mass significantly decreases with increasing the residence time and temperature of treatment. As a result, the crystalline proportion of wood increases in wood cellulose. At the same time, during a heat treatment, esterification of hydroxyl groups and cross-linking reactions take place. As a consequence of the factors above, the $\mathrm{OH}$ groups available for moisture adsorption in wood are reduced, decreasing the higroscopicity and EMC of wood. It is also mentioned the increase in lignin proportion, which improves the hydrophobic properties of the heat treated wood.

Several previous studies have investigated the effect of heat treatment on the mechanical properties of wood. In general, these studies report a considerable reduction of the shear modulus of rupture (de Moura et al. 2012) and bending (Kamdem et al. 2002, Awoyemi and Westermark 2005, de Moura et al. 2012), mainly at temperatures above $200^{\circ} \mathrm{C}$. It is expected that these changes in mechanical properties might have an effect on machining properties and surface quality of machined wood.

De Moura et al. (2011) evaluated the effect of three rake angles in peripheral planning, and three sanding schedules on the surface quality of Eucalyptus grandis and Pinus caribaea var. hondurensis treated with four levels of heat treatment. The authors demonstrated that heat treated samples provided rougher surfaces after machining, in comparison with non-treated samples. This effect became more severe as the maximum temperature of heat treatment increased.

The knowledge on the surface quality required for manufacturing a wood product is important to avoid unnecessary expenses of materials and time during wood preparation (Hoadley 2000). In this context, this study aimed to evaluate surface roughness of heat treated Eucalyptus grandis wood after peripheral planning and sanding, both performed in directions to the grain and against the grain. For machining tests, workpieces were collected from two different regions in the radial direction.

\section{Material}

\section{MATERIAL AND METHODS}

Samples were collected from six 23 years-old Eucalyptus grandis trees. Each tree provided three $2.0 \mathrm{~m}$ long logs, obtained at stem heights above $1,3 \mathrm{~m}$ from the soil. These logs provided samples from two regions in the radial direction of stem: internal, nearby the pit; external, nearby the bark.

A total of 208 boards were obtained from logs and the machining tests were performed according to ASTM D 1666-95 standard. These boards were machined to $125 \mathrm{~mm}(\mathrm{~T})$ width, 25mm (R) thickness, and $500 \mathrm{~mm}(\mathrm{~L})$ length, for the following tests:

1) Surface roughness analysis in the radial direction of stem, and

2) Surface roughness analysis in heat treated and control samples.

\section{Heat treatment}

104 samples underwent heat treatment in an electrical resistance oven, equipped with a timer and temperature control system on the presence of oxygen. Heat treatment was programmed to a total of 23400 second duration, and maximum temperature of $190^{\circ} \mathrm{C}$. The heating schedule was performed in four steps, as illustrated in figure 1 . The initial moisture content of wood before heat treatment was about $12 \%$. 


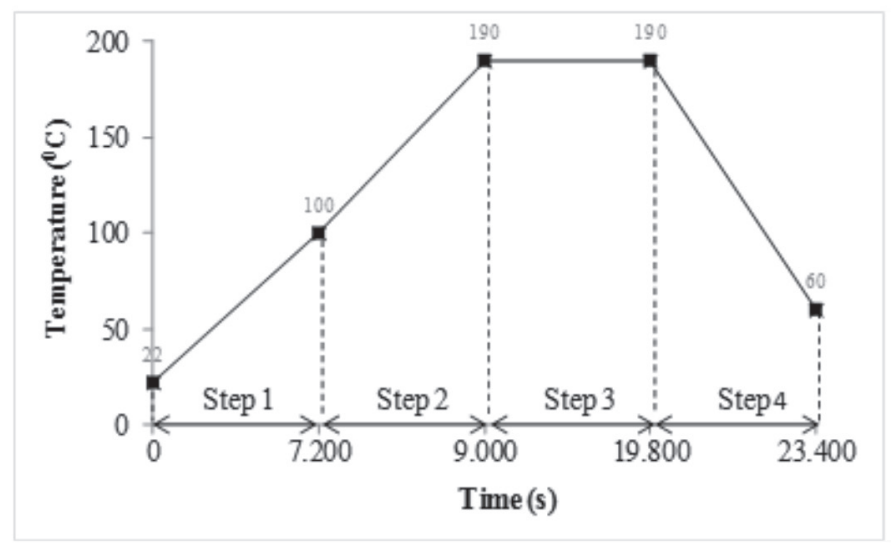

Figure 1. Heat treatment applied on Eucalyptus grandis wood.

\section{Machining tests}

After heat treatment, the 208 samples (104 heat treated and 104 untreated) underwent planning and sanding tests, carried out in the directions to the grain and against the grain. For planning and sanding tests at different machining directions, each $125 \mathrm{~mm}(\mathrm{~T})$ width sample was longitudinally sectioned, providing two $62 \mathrm{~mm}(\mathrm{~T})$ width paired samples. For each of these paired samples, the wood grain angle was measured relative to the plan of machining tests. During machining tests, half of these samples were machined to the grain and other half were machined against the grain.

Planning was performed with a cabinet single-axed straight-knife peripheral planer, provided with two freshly-sharpened knives installed in a $3400 \mathrm{rpm}$ cutterhead. The planer was set to work at 1,6 mm cutting depth, and $15 \mathrm{~m} / \mathrm{min}$ feed speed, which results in approximately 10 knife marks per inch. Knife rake and clearance angles were set to $15^{\circ}$ and $16^{\circ}$, respectively. Planer feeding was carried out parallel to the longitudinal axis of samples.

Sanding was carried out by means of a power-stroke sander, equipped with a cloth-backed sandpaper belt, with $15,0 \mathrm{~cm}$ width and $6.8-\mathrm{m}$ length. The sanding schedule involved two steps: 80 grit and 100 grit. Sanding was carried out parallel to the longitudinal axis of samples. Each sample was kept in contact with the sandpaper during 2 minutes.

\section{Surface roughness tests}

Surface roughness analysis was performed according to ISO 4287-1/1984. Roughness measurements were carried out with a portative stylus-contacting type roughness meter. The pick-up travel length and cut-off length were set to $15 \mathrm{~mm}$ and $2.5 \mathrm{~mm}$, respectively. Measurements were performed at $0,5 \mathrm{~mm} / \mathrm{s}$ stylus speed. The roughness average $(\mathrm{Ra})$ was calculated as an average of five consecutive cut-off lengths for each pick-up travel length. In this study, Ra was assessed across the grain orientation (Ra $\perp$; for both surfacing methods), and along the grain orientation (Ra\|; for planed surfaces only).

\section{Statistical analysis}

Analysis of variance (ANOVA) at 5\% significance level was applied for detecting differences among means as a function of heat treatment and radial stem direction. In case of variables having the null hypothesis (Ho) rejected by ANOVA, Tukey's multiple comparison tests at 5\% significance level were applied. 


\section{RESULTS AND DISCUSSION}

\section{Roughness on planed surfaces}

The average values of surface roughness of Eucalyptus grandis measured across $(\mathrm{Ra} \perp)$ and along the grain orientation $(\mathrm{Ra} \|)$, for different sampling positions in the radial direction of the stem, feed directions in planning, and heat treatment conditions are compiled in table 1.

As observed in table 1, the roughness average (Ra), measured after planning, was not significantly affected by sampling position, feed direction, and previous heat treatment condition.

Table 1. Surface roughness average measured across $(\mathrm{Ra} \perp)$ and along the grain orientation $(\mathrm{Ra} \|)$ for planed Eucalyptus grandis wood, considering different sampling positions in the radial direction, feed directions, and heat treatment conditions.

\begin{tabular}{|c|c|c|c|c|c|}
\hline \multirow[b]{3}{*}{ Sampling position } & \multirow{2}{*}{\multicolumn{2}{|c|}{$\mathrm{Ra} \perp(\mu \mathrm{m})$}} & \multirow{2}{*}{\multicolumn{2}{|c|}{$\mathrm{Ra} \|(\mu \mathrm{m})$}} & \multirow[b]{3}{*}{$\begin{array}{c}\text { Heat } \\
\text { treatment }\end{array}$} \\
\hline & & & & & \\
\hline & $\begin{array}{l}\text { To the } \\
\text { grain }\end{array}$ & $\begin{array}{l}\text { Against } \\
\text { the grain }\end{array}$ & $\begin{array}{l}\text { To the } \\
\text { grain }\end{array}$ & $\begin{array}{l}\text { Against } \\
\text { the grain }\end{array}$ & \\
\hline Internal & $11,24(\mathrm{a})$ & $13,40(a)$ & 3,65 (a) & 5,30 (a) & \multirow{4}{*}{ Control (a) } \\
\hline External & 11,15 (a) & $12,48(a)$ & 3,82 (a) & $4,45(a)$ & \\
\hline Average & 11,19 (A) & 12,94 (B) & 3,73 (A) & 4,87 (B) & \\
\hline Average Control & \multicolumn{2}{|c|}{12,06} & \multicolumn{2}{|c|}{4,30} & \\
\hline Internal & 12,18 (a) & $13,16(a)$ & 4,04 (a) & 4,84 (a) & \multirow{4}{*}{ HT (a) } \\
\hline External & 12,66 (a) & 12,77 (a) & 4,75 (a) & 4,90 (a) & \\
\hline Average & 12,42 (A) & $12,97(\mathrm{~A})$ & $4,40(\mathrm{~A})$ & 4,87 (A) & \\
\hline Average HT & \multicolumn{2}{|c|}{12,69} & \multicolumn{2}{|c|}{4,63} & \\
\hline
\end{tabular}

Control (not heat treated), HT (heat treated). Means followed by distinct letters are significantly different (Tukey's test at 5\% significance). Lowercase letters are for comparisons between sampling positions (internal and external) within a same column, for heat treatment conditions separately. Underlined lowercase letters are for comparisons between heat treatment conditions (Control and HT) within a same column. Uppercase letters are for comparisons between feed directions (to the grain and against the grain) within a same line, for roughness measurements across and along the grain orientation separately.

As expected, surface roughness was higher in samples planed against the grain than in those planed to the grain. However, according to ANOVA, this effect was only significantly perceived in control samples. This result suggests that heat treatment can minimize the occurrence of machining defects when planning against the grain. Figure 2 shows the variation of surface roughness as a function of feed direction in planning, as well as multiple comparisons (Tukey's test) among averages, for not heat treated samples. 


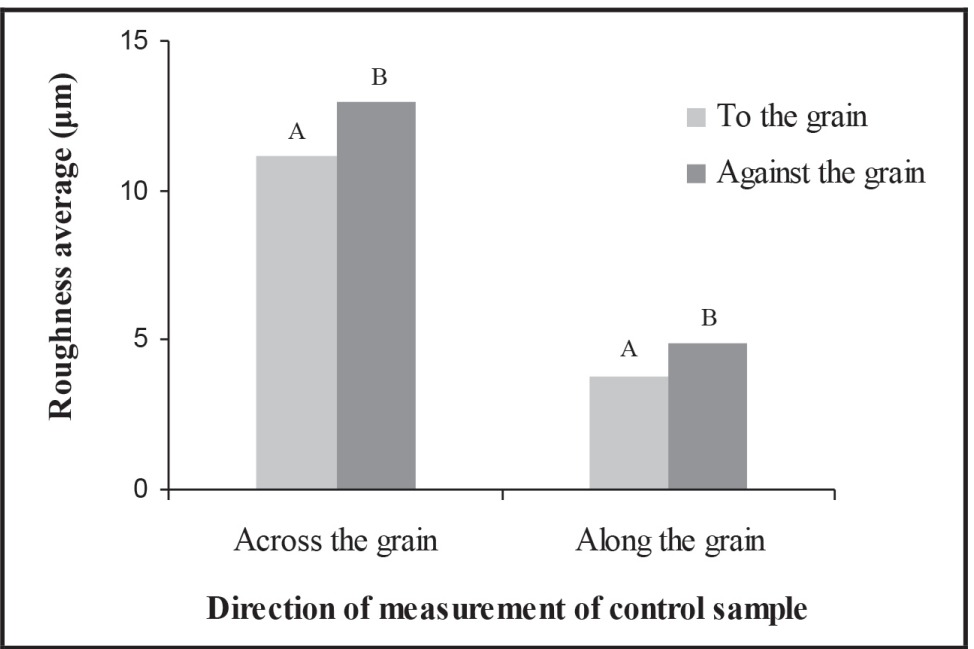

Figure 2. Surface roughness measured across and along the grain orientation on not heat treated (Control) samples, as a function of feed direction in planning.

Means followed by distinct letters are significantly different, for Ra measurements across and along the grain orientation separately.

In general, previous application of heat treatment did not cause significant differences in surface roughness of Eucalyptus grandis wood after planning.

Information on eucalyptus surface roughness measured separately across and along the grain orientation is very scarce. Lopes (2007) evaluated roughness parallel to the grain in planed surfaces of Eucalyptus grandis as a function of feed speed. The authors observed that surface roughness decreased as feed speed decreased. For a $0,25 \mathrm{~m} / \mathrm{s}$ feed speed during planning, they report a 3,76 $\mu \mathrm{m} \mathrm{Ra}$. For Eucalyptus camaldulensis samples previously treated by heating, Unsal and Ayrilmis (2005) applied planning at $0,027 \mathrm{~m} / \mathrm{s}$ feed speed and $45^{\circ} \mathrm{knife}$ rake angle. The authors verified that roughness, measured across the grain orientation after planning, was lower in samples previously treated by heating in comparison with control samples. This latter effect was more pronounced as the maximum temperature increased and heating rate decreased. For $120^{\circ} \mathrm{C}$ temperature and permanence times of 2,6 and 10 hours, Ra provided values of $9,27 \mu \mathrm{m} ; 9,16 \mu \mathrm{m}$; and $8,90 \mu \mathrm{m}$; respectively; for $150^{\circ} \mathrm{C}$ temperature and permanence times of 2,6 and 10 hours, Ra provided values of $8,39 \mu \mathrm{m}, 8,13 \mu \mathrm{m}$, and 7,98 $\mu \mathrm{m}$, respectively; for $180^{\circ} \mathrm{C}$ temperature and permanence times of 2, 6 and 10 hours, Ra provided values of 7,46 $\mu \mathrm{m} ; 7,39 \mu \mathrm{m}$ and $7,21 \mu \mathrm{m}$; respectively. For control samples, Ra was $10,0 \mu \mathrm{m}$. In the present study, roughness values are very similar to those reported by Lopes (2007), and Unsal and Ayrilmis (2005).

The difference between surface roughness measured across and along the grain orientation has already been reported in previous works. According to de Moura (2006), values of roughness measured across the grain $(\mathrm{Ra} \perp)$ are usually higher than those observed along the grain $(\mathrm{Ra}||)$, and both increase at higher feed speeds in planning.

The increase in surface roughness after planning against the grain has already been mentioned in several previous studies (SENAI - CETMAM 2000, Leitz Ferramentas para Madeira 1995, de Moura 2006). A good quality cut is usually obtained when planning to the grain, mainly in the tangential plan of boards, which also decreases energy consumption during cutting and planer feeding. Cutting against the grain might produce a series of imperfections on the surface, by tearing out superficial cells or tissues, due to ruptures that propagate obliquely below the cutting plan: as a consequence, higher surface roughness is produced. 


\section{Roughness on sanded surfaces}

The average values of surface roughness of Eucalyptus grandis measured across the grain orientation $(\mathrm{Ra} \perp)$, for different sampling positions in the radial direction of the stem, feed directions in an 80-100 grit sanding schedule, and heat treatment conditions are compiled in table 2.

As observed in table 2, the roughness average (Ra), measured after sanding, was not significantly affected by sampling position. However, both feed direction and previous heat treatment condition had an effect on the roughness parameter.

Table 2. Surface roughness measured across the grain orientation $(\mathrm{Ra} \perp$ ) for Eucalyptus grandis wood sanded with an 80-100 grit schedule, considering different sampling positions in the radial direction, feed directions, and heat treatment conditions.

\begin{tabular}{|c|c|c|c|c|c|}
\hline \multirow{3}{*}{ Sampling position } & \multicolumn{4}{|c|}{$\operatorname{Ra} \perp(\mu \mathrm{m})$} & \multirow{3}{*}{$\begin{array}{c}\text { Heat } \\
\text { treatment }\end{array}$} \\
\hline & \multicolumn{2}{|c|}{80 grit } & \multicolumn{2}{|c|}{100 grit } & \\
\hline & $\begin{array}{l}\text { To the } \\
\text { grain }\end{array}$ & \begin{tabular}{|c|}
$\begin{array}{c}\text { Against the } \\
\text { grain }\end{array}$ \\
\end{tabular} & $\begin{array}{l}\text { To the } \\
\text { grain }\end{array}$ & $\begin{array}{c}\text { Against the } \\
\text { grain }\end{array}$ & \\
\hline Internal & 7,95 (a) & 8,19 (a) & $6,70(a)$ & 7,73 (a) & \multirow{4}{*}{ Control (a) } \\
\hline External & $7,54(\mathrm{a})$ & 8,18 (a) & 6,75 (a) & $7,52(a)$ & \\
\hline Average & 7,74 (A) & 8,19 (B) & $6,72(A)$ & $7,62(B)$ & \\
\hline Average Control & \multicolumn{2}{|c|}{7,97} & \multicolumn{2}{|c|}{7,17} & \\
\hline Internal & 8,84 (a) & 9,16 (a) & 7,07 (a) & 8,11 (a) & \multirow{3}{*}{ HT (b) } \\
\hline External & 8,99 (a) & 9,61 (a) & 7,36 (a) & 7,89 (a) & \\
\hline Average & $8,91(\mathrm{~A})$ & 9,38 (B) & $7,21(\mathrm{~A})$ & $8,00(B)$ & \\
\hline Average HT & \multicolumn{2}{|c|}{9,15} & \multicolumn{2}{|c|}{7,61} & \\
\hline
\end{tabular}

Control (not heat treated), HT (heat treated). Means followed by distinct letters are significantly different (Tukey's test at 5\% significance). Lowercase letters are for comparisons between sampling positions (internal and external) within a same column, for heat treatment conditions separately. Underlined lowercase letters are for comparisons between heat treatment conditions (Control and HT) within a same column. Uppercase letters are for comparisons between feed directions (to the grain and against the grain) within a same line, for 80 grit and 100 grit sandpapers separately.

Similarly to the behavior observed after planning, Ra was higher in surfaces sanded against the grain, for both grit sizes studied. Figures 3 and 4 illustrate the variation of surface roughness as a function of feed direction in sanding, as well as Tukey's multiple comparisons among means. 


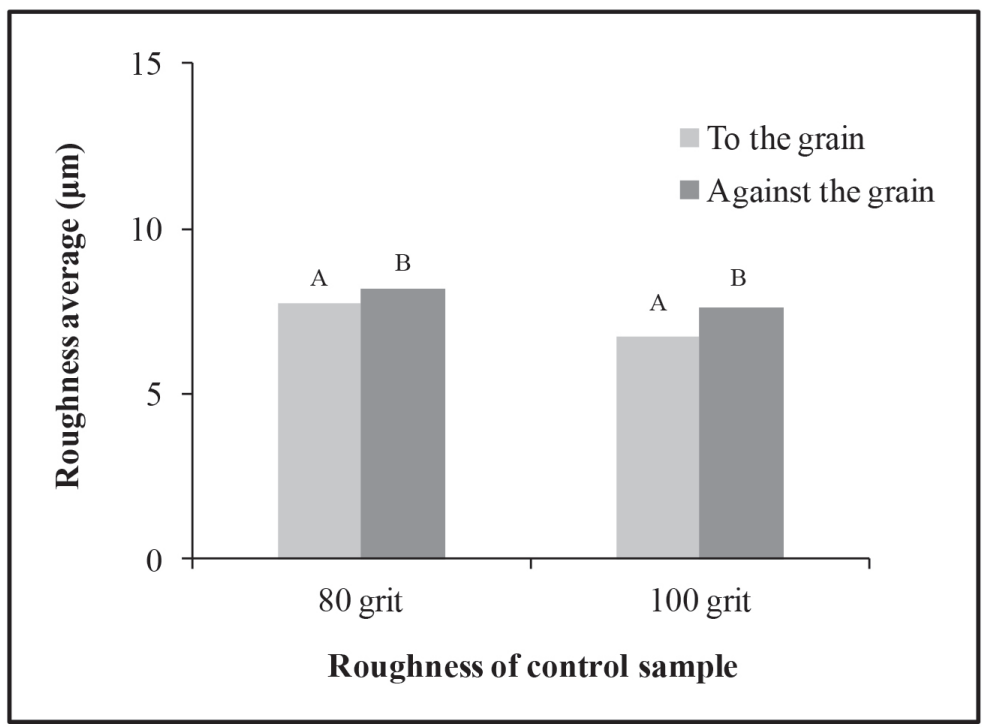

Figure 3. Surface roughness measured across the grain orientation on not heat treated (Control) samples, as a function of feed direction in sanding, for two sandpaper grit sizes.

Means followed by distinct letters are significantly different, for 80 grit and 100 grit separately.

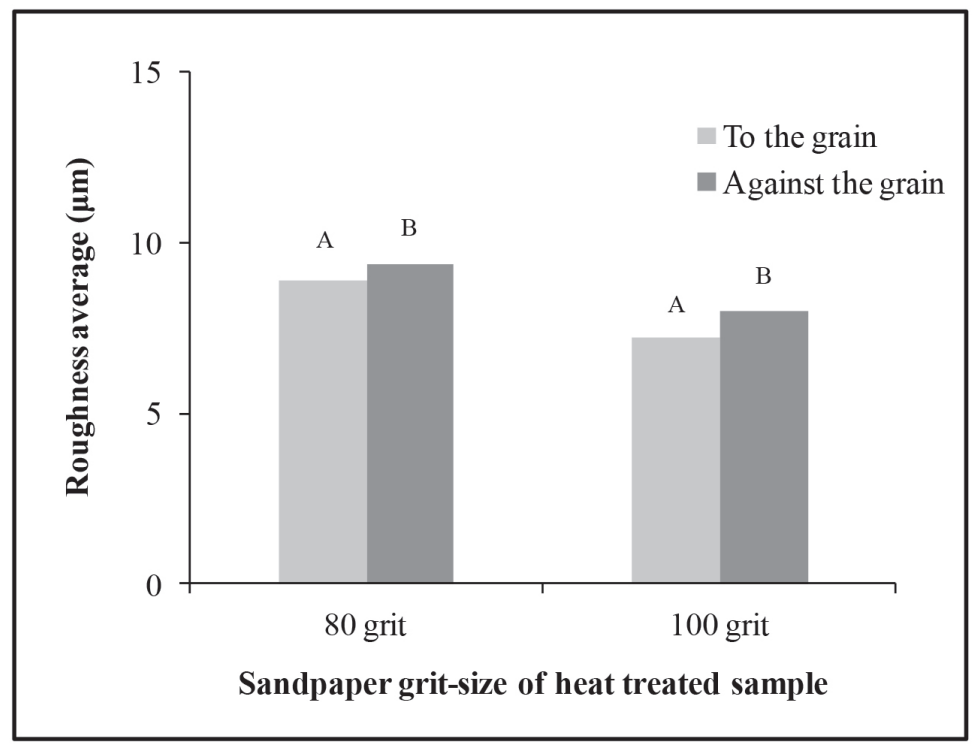

Figure 4. Surface roughness measured across the grain orientation on heat treated (HT) samples, as a function of feed direction in sanding, for two sandpaper grit sizes.

Means followed by distinct letters are significantly different, fr 80 grit and 100 grit separately.

The surface roughness of sanded surfaces was significantly affected by previous heat treatment and sandpaper grit sizes. Figure 5 shows the variation of surface roughness on sanded surfaces as a function previous application of heat treatment and grit sizes used in sanding, including comparisons among means by Tukey's tests. Roughness of sanded surfaces was higher in previously heat treated samples $(8,38 \mu \mathrm{m})$ than in non-treated samples $(7,57 \mu \mathrm{m}$; all variables pooled). As expected, sanding with 100 grit sandpaper significantly reduced surface roughness in comparison with 80 grit sanding. This reduction was more pronounced in heat treated samples (17\%) than in non-treated samples $(10 \%)$. 


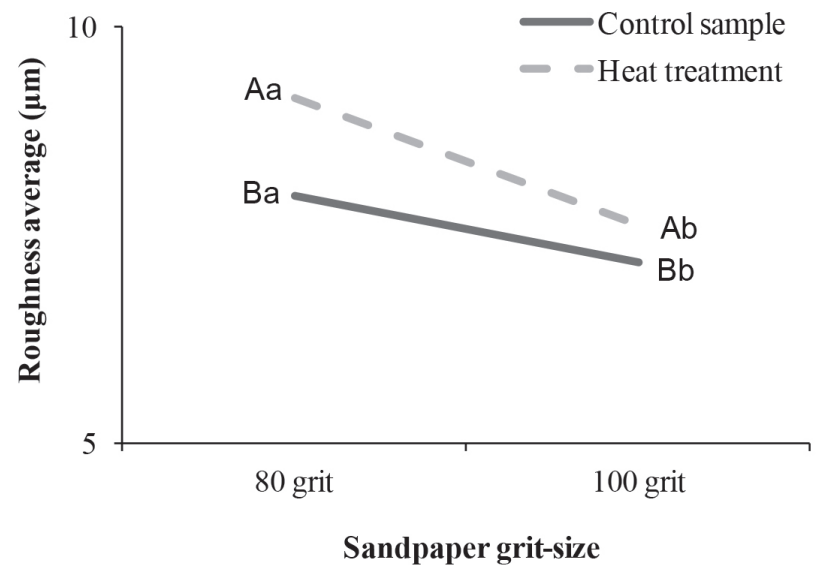

Figure 5. Surface roughness measured across the grain orientation, as a function of two heat treatment conditions and sandpaper grit sizes.

Means followed by distinct letters are significantly different. Uppercase letters are for comparison between heat treatment conditions (Control; HT). Lowercase letters are for comparison between grit sizes ( 80 grit; 100 grit).

In this study, the values of surface roughness are very similar to those previously reported by de Moura et al. (2011) for Eucalyptus grandis sanded wood. According to the authors, as the maximum temperatures of heat treatment increased, the roughness of sanded surfaces obtained for a given sanding schedule also increased. The wood mechanical strength decreased as the maximum temperature of heat treatment increased. Thus, for samples treated at the highest temperatures, abrasive grains could further penetrate the surface, due to its lowest mechanical strength.

De Moura et al. (2011) also reported that the 100 grit sandpaper strongly reduced surface roughness of Eucalyptus grandis and Pinus caribaea var. hondurensis woods previously sanded with 80-grit sandpaper. However, the use of a finer grit size (120 grit) was not effective in further reducing wood surface roughness.

\section{CONCLUSIONS}

For both surfacing methods tested in this study, surface roughness has not varied as a function of radial sampling position.

After planning, surface roughness measured across the grain orientation was higher than that measured along the grain.

Surface roughness was higher in samples planed against the grain than in those planed to the grain. However, this effect was only significantly perceived in control samples. This result suggests that heat treatment can minimize the occurrence of machining defects when planning against the grain.

For both sandpaper grit sizes tested, roughness of sanded surfaces was higher in previously heat treated samples than in non-treated samples. Moreover, surface roughness was higher in samples sanded against the grain than in those planed to the grain. Sanding with 100 grit sandpaper significantly reduced surface roughness in comparison with 80 grit sanding. 


\section{ACKNOWLEDGMENTS}

The authors acknowledge "CAPES (Coordenação de Aperfeiçoamento de Pessoal de Nível Superior)" for financial support; "QUINVALE Florestal Ltda." for providing Eucalyptus grandis trees for this study; and "Serraria de Artefatos de Madeira e Serviços Ltda." for wood processing.

\section{REFERENCES}

ASTM, American society for testing and material. 1995. Standard method for machining tests of wood and wood base materials. ASTM D 1666. Philaldelphia, p. 226- 245.

Awoyemi, L.; Westermark, U. 2005. Effects of borate impregnation on the response of wood strength to heat treatment. Wood Science and Technology 39:484-491.

Bourgois, P.J.; Guyonnet, R. 1988. Characterization and analysis of torrefied wood. Wood science and Technology 22:143-155.

Borrega, M.; Kärenlampi, P.P. 2008. Mechanical behavior of heat-treated spruce (Picea abies) wood at constant moisture content and ambient humidity. Holz als Roh- und Werkstoff 66:63-69.

Esteves, B.; Marques, A.V.; Domingos, I.; Pereira, H. 2007. Influence of steam heating on the properties of pine (Pinus pinaster) and eucalypt (Eucalyptus globulus) wood. Wood Science and Technology 41(3): 193-207.

Garcia, R.A.; Carvalho, A.M.; Latorraca, J.V.F.; Matos, J.L.M.; Santos, W.A.; Silva, R.F.M. 2010. Nondestructive evaluation of heat-treated Eucalyptus grandis Hill ex Maiden wood using stress wave method. Wood Science and Technology 46(1):41-52.

Hoadley, R.B. 2000. Understanding wood. A craftsman's guide to wood technology. The Taunton Press, Inc.

International Organization for Standardization. 1984. Surface roughness. Terminology. Part 1: Surface and its parameters. ISO 4287-1/1984. Publisher: International Organization for Standardization (ISO). Geneva. 25p

Kilic, M.; Hiziroglu, S.; Burdurlu, E. 2006. Effect of machining on surface roughness of wood. Building and Environment 41(8):1074-1078.

Lopes, C.S.D. 2007. Caracterização da madeira de três espécies de eucalipto para uso em movelaria. M.Sc. Dissertation, University of São Paulo, Brasil, 88p.

Leitz Ferramentas para Madeira. 1995. Madeira como matéria-prima. Madeira \& Cia, Curitiba, Brasil. 3 (19):18-21.

De Moura, L.F. 2006. Étude de trois procédés de finition des surfaces du bois d'érable à sucre pour fins de vernissage. Ph.D. Thesis, Laval University, Quebec, Canadá, 181p.

De Moura, L.F.; Brito, J.O.; Nolasco, A.M.; Uliana, L.R. 2011. Effect of thermal rectification on machinability of Eucalyptus grandis and Pinus caribaea var. hondurensis woods. European Journal of Wood and Wood Products 69(4):641-648. 
De Moura, L.F.; Brito, J.O.; Bortoletto Júnior, G. 2012. Efeitos da termorretificação na perda de massa e propriedades mecânicas de Eucalyptus grandis e Pinus caribaea var. hondurensis. Revista Floresta 42(2):305-314.

Kamdem, D. P.; Pizzi, A.; Jermannaud, A. 2002. Durability of heat-treated wood. Holz als Rohund Werkstoff 60(1):1-6.

Obataya, E.; Tanaka, F.; Norimoto, M.; Tomito, B. 2000. Hygroscopicity of heat-treated wood 1. Effects of after treatments on the hygroscopicity of heat-treated wood. Journal of the Japan Wood Research Society 46:77-87.

Olek, W.; Bonarski, J.T. 2008. Texture changes in thermally modified wood. Archives of Metallurgy and Materials 53(1):207-211.

Poncsak, S.; Kocaefe, D.; Bouazara, M.; Pichette, A. 2005. Effect of high temperature treatment on the mechanical properties of birch (Betula papyrifera). Wood Science and Technology 66(1):39-49.

Sandak, J.; Negri, M. 2005. Wood surface roughness - what is it? In: Proceedings of the 17th International Wood Machining Seminar (IWMS 17), Rosenheim, German, 26-28 September.

SENAI - CETMAM - NAT. 2000. Processamento mecânico do eucalipto: secagem - usinagem acabamento de superfície. Paraná. Brasil. 50 p.

Unsal, O.; Ayrilmis, N. 2005. Variations in compression strength and surface roughness of heattreated Turkish river red gun (Eucalyptus camaldulensis) wood. Journal of Wood Science 51:405-409. 